\title{
Seroprevalence of human Echinococcosis in a community living around slaughterhouses in Western Province in Sri Lanka
}

Keywords:

Posted Date: December 15th, 2020

DOl: https://doi.org/10.21203/rs.3.rs-30794/v2

License: (c) (i) This work is licensed under a Creative Commons Attribution 4.0 International License. Read Full License 


\section{Abstract}

The authors have requested that this preprint be removed from Research Square. 